\title{
Mapping and exploring the distribution of the Vulnerable grey-winged cotinga Tijuca condita
}

\author{
Maria Alice S. Alves, Stuart L. Pimm, Alline Storni, Marcos A. Raposo \\ M. De L. Brooke, Grant Harris, Andy Foster and Clinton N. Jenkins
}

\begin{abstract}
The grey-winged cotinga Tijuca condita was first described in 1980 from an old specimen, misidentified as a congener. Field observations came later, from two remote, high-elevation forests in the mountains of Rio de Janeiro, Brazil. Both involved only a few pairs of birds at best, making this species one of the least known in the world. Accurately defining the locations this species inhabits is an obvious prerequisite for designing conservation strategies to protect it. Using remotely sensed data on elevation and forest cover we mapped this species' habitat and predicted six more sites where it may occur. Field surveys confirmed two of them, doubling the known range of the species. The two easternmost predicted sites did not contain the species but these areas have less annual rainfall than other sites, which may explain the absences. This research serves as an important guide to conservation actions, for it uncovered biologically important areas for this species that had been previously overlooked. It has also measured the remaining habitat of the species so that any future losses can be detected.
\end{abstract}

Keywords Atlantic Forest, Brazil, endemic species, greywinged cotinga, remote sensing, Rio de Janeiro, Tijuca condita.

\footnotetext{
Maria Alice S. Alves Departamento de Ecologia, Universidade do Estado do Rio de Janeiro, Rua São Francisco Xavier 524, Rio de Janeiro, RJ, 20550011, Brazil.

Stuart L. Pimm, Grant Harris* and Clinton N. Jenkins (Corresponding author) Nicholas School of the Environment, Duke University, Box 90328, LSRC A201, Durham, NC 27708, USA. E-mail clinton.jenkins@duke.edu

Alline STORNI ${ }^{\dagger}$ Programa de Pos-Graduação em Biologia, Universidade do Estado do Rio de Janeiro, Rua São Francisco Xavier 524, Rio de Janeiro, RJ, 20550-011, Brazil.

Marcos A. Raposo Setor de Ornitologia, Departamento de Vertebrados, Museu Nacional/UFRJ, Quinta da Boa Vista s/n, Rio de Janeiro, RJ, 20940040, Brazil.

M. DE L. BRooke Department of Zoology, University of Cambridge, Downing Street, Cambridge, CB2 3EJ, UK.

Andy Foster Serra dos Tucanos Lodge, Caixa Postal 98125, Cachoeiras de Macacu, RJ, 28680-000, Brazil.

${ }^{*}$ Current address: US Fish \& Wildlife Service, PO Box 1306, Albuquerque, NM 87103, USA.

${ }^{\dagger}$ Current address: Instituto de Desenvolvimento Sustentável Mamirauá, Programa de Ecoturismo, Avenida Brasil, 197, Tefé, Amazonas, 69470-000, Brazil.

Received 29 May 2007. Revision requested 21 August 2007.

Accepted 28 November 2007.
}

\section{Introduction}

T xtinction rates for birds, already a hundred times Chigher than the expected background rate, are likely to increase substantially (Pimm et al., 1995, 2006). However, species differ greatly in their risk of extinction. Those with small ranges are disproportionately threatened (Manne et al., 1999) and geographically concentrated (Pimm \& Jenkins, 2005). Knowing where such high levels of endemism reside is a key international strategy for biodiversity protection. Their intersection with high levels of human damage defines the term biodiversity hotspot (Myers, 1988, 1990; Myers et al., 2000).

Understanding local distributions of threatened species is an essential practical step in their protection. Even for wellstudied groups, such as birds, published maps often show only a vague extent of occurrence rather than a detailed distribution. Traditional approaches to mapping distributions, essentially one observation at a time, are too labourintensive to provide rapid recommendations of where conservation priorities should be within a hotspot. Conservationists need a simple, accurate and efficient approach.

Elsewhere, we have documented efforts to map conservation priorities in the Brazilian state of Rio de Janeiro (Jenkins, 2003; Rocha et al., 2003; Harris et al., 2005; Jenkins \& Pimm, 2006). The state holds the greatest density of threatened birds within the Americas (Manne et al., 1999; Myers et al., 2000; Harris et al., 2005; Jenkins \& Pimm, 2006). Of the 653 species of bird known to occur in the state, 12.5\% are regionally threatened (Alves et al., 2000). One of those species is the grey-winged cotinga Tijuca condita, endemic to the state, with a small range, and categorized as Vulnerable on the IUCN Red List (IUCN, 2007) under criterion D2 (very small population; IUCN, 2001). The assessment notes, however, that were there any evidence of damage to its habitat, it would be categorized as Endangered (IUCN, 2007).

Snow (1980) originally described $T$. condita from a female collected in 1942 at Fazenda Guinle, above Teresópolis, at approximately $22^{\circ} 27^{\prime} \mathrm{S} 43^{\circ} \mathrm{Oo}^{\prime} \mathrm{W}$. The specimen had been labelled as Tijuca atra, the black and gold cotinga, a more common congener also living in high elevation forest. No altitude was included in the record. The city is just below 1,000 $\mathrm{m}$ but the Serra dos Órgãos mountains immediately to the north rise above 2,000 $\mathrm{m}$. Shortly thereafter Scott \& Brooke (1993) found the species in two locations in high elevation forests in Serra do Tinguá and Serra dos Órgãos (Fig. 1). The former location is difficult to 
access (see below), and the latter is the one location where birdwatchers regularly look for the species along a few hundred metres of trail.

From our earlier studies, the predicted range for $T$. condita far exceeded the two known localities (Harris \& Pimm, 2004; Pimm \& Jenkins, 2005; Jenkins \& Pimm, 2006). Possibly the species is more widespread, living in inaccessible and biologically unexplored terrain. Our habitat modelling approach used forest cover and elevation data to refine the relatively crude range maps found in field guides and similar sources. The predicted distribution maps are fine-scaled (c. 1 ha resolution).

The objective of the present study was to evaluate these earlier model predictions and evaluate the conservation status of T. condita. Here, we report our search for new areas of occurrence of $T$. condita based on a map of potential habitat. This habitat map also quantifies the available habitat so that any future losses can be measured.

\section{Methods}

The model

The specific habitat needs of $T$. condita are uncertain, other than that it occurs in cloud forest at high elevations in Rio de Janeiro state. To parameterize the habitat model and guide the field expeditions, we searched the literature for all published information about T. condita (Snow, 1980, 1982; Collar et al., 1992; Scott \& Brooke, 1993).

The model had three steps. The first restricted the search area to the suspected maximum range of the species. This included the central mountains of Rio de Janeiro from Tinguá in the west to Desengano in the east (Fig. 1). No other mountains higher than $1,400 \mathrm{~m}$ are within $70 \mathrm{~km}$ of the defined range. The second step removed all nonforest areas within that range, as this is a forest-dependent species. The third step eliminated areas $<1,400 \mathrm{~m}$, which is approximately the lower of the two known elevations, from Tinguá (Scott \& Brooke, 1993). The final habitat map (Fig. 1) includes only forest, at potentially suitable elevations, within the likely range of the species.

The forest map derives from Landsat 7 ETM+ satellite imagery (paths 216-218/rows 75 \& 76) collected during the drier, and less cloudy, winter season (August) of 1999 and 2000. We classified the imagery into forest and non-forest classes using a maximum likelihood classifier in the software ERDAS Imagine v. 8.7 (ERDAS, Norcross, USA). Ground truth data and our knowledge of the region guided the definition of training samples. The accuracy of the forest map was estimated at $89 \%$ using 200 random points

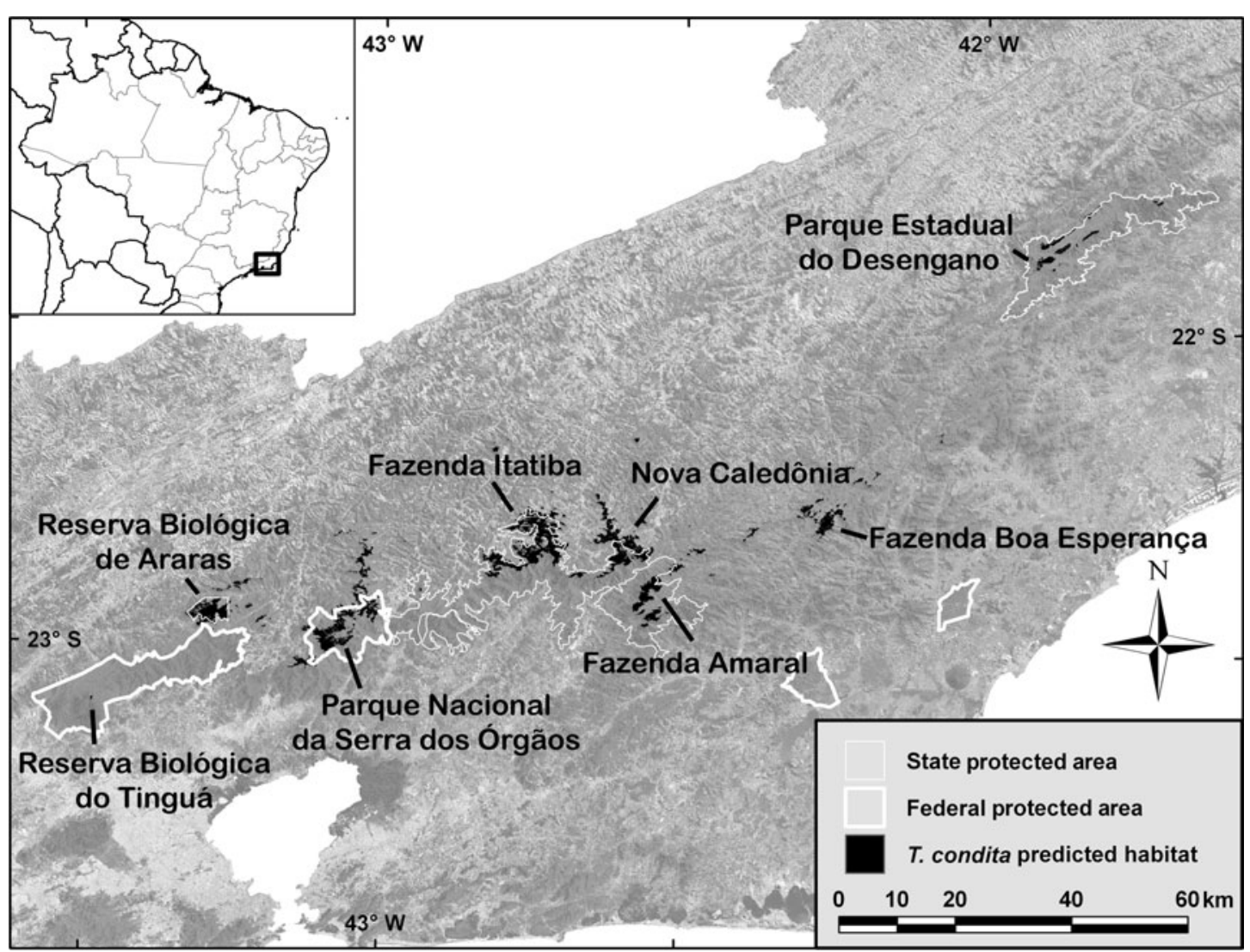

FIG. 1 Rio de Janeiro state with overlay of predicted T. condita habitat, survey sites and major protected areas. The background is a mosaic of Landsat ETM+ satellite images. The rectangle on the inset indicates the location of the main map in Brazil. 
classified using aerial photography, high-resolution satellite imagery, and ground-truthing. Elevation data are from the Shuttle Radar Topography Mission (Rabus et al., 2003) and have a horizontal resolution of $90 \mathrm{~m}$.

\section{The field surveys}

Before the surveys most of the authors visited the one site accessible by trail in the Parque Nacional da Serra dos Órgãos to become familiar with the species and its vocalization. Teams then visited six other sites (Fig. 1), to field test the model predictions. Each site had $>10 \mathrm{~km}^{2}$ of predicted habitat and was isolated from other large patches of predicted habitat.

The surveys took place in December 2003 and January 2004, the period when $T$. condita males are likely to be vocal and may be breeding (Scott \& Brooke, 1993). We visited an additional site in July 2005 but only for 1 day. The field teams were of 3-4 people at each site. Surveys included visual searches, mist netting and playback of $T$. condita song, all georeferenced using a global positioning system. We used standardized field protocols in each site. Five mist nets $(12 \times 2.5 \mathrm{~m}, 32 \mathrm{~mm}$ mesh $)$ were exposed for 7 hours per day starting in early morning on 2 consecutive days, totalling 14 hours per site (except in Desengano, where, because of bad weather, we had only 4 hours of nets exposed on the first day). Playback of $T$. condita calls and tape recordings of other species were with a tape recorder and microdirectional microphone. Playbacks lasted for c. 5 minutes, with pauses of at least 10 minutes between sessions. Total playback time was a minimum of 1 hour and up to 3 hours per day. We also used a portable digital player to help with bird sound identification in the field.

We obtained digital maps of conservation units for the region from IBAMA (2007) to determine the formal protection status of the areas of predicted habitat.

\section{Results}

We confirmed two new locations for T. condita and thus doubled the number of known areas where the species occurs. When the species was present in an area it answered quickly to playback, usually within the first hour.

The model predicted c. $200 \mathrm{~km}^{2}$ of potential habitat for T. condita (Table 1), clustered in eight large sites of mostly continuous forest with some satellite patches along the central mountains of Rio de Janeiro state (Fig. 1). All of the habitat patches are within $25 \mathrm{~km}$ of another large patch, except for Desengano, which is $>40 \mathrm{~km}$ from the nearest large patch. Approximately $130 \mathrm{~km}^{2}(64 \%)$ of the habitat is within protected areas (i.e. biological reserves, state or national parks).

Reserva Biológica do Tinguá Difficult terrain prevented access to the predicted location. Scott \& Brooke (1993) found their first $T$. condita at c. 1,375 m, but only after a long and difficult trip, working their way from lower elevations. In December 2003 we visited an accessible area below the predicted site and MdeLB found the base of access to the original sampling site of the species from 20 years earlier. It was then possible to plot the site of the original sighting using a local map. This matched the predicted site for Tinguá.

Reserva Biológica de Araras The survey team camped at 1,650 m over 11-13 December 2003. At 07.45 on 12 December, from a ridge, they observed a single $T$. condita answering a playback on a forested slope $30-50 \mathrm{~m}$ away. This bird (possibly a male) answered the playback weakly and was located $3 \mathrm{~m}$ from the ground in a tree c. $6 \mathrm{~m}$ high on a forested slope. On the same day, at 14.30, c. 100-200 m below the first location, the team sighted T. condita 100$200 \mathrm{~m}$ from the first location, although it is uncertain if it was the same individual. Although mist nets were set near where the team observed T. condita, no individuals were captured and none were observed the following day. The observed birds were in cloud forest rich in bromeliads, with

TABLE 1 Sites (Fig. 1), area of habitat, altitude of survey, and results of surveys for T. condita.

\begin{tabular}{lccc}
\hline Site number \& name (coordinates)* & Area of habitat $\left(\mathrm{km}^{2}\right)$ & Survey altitude $(\mathrm{m})$ & Detected? \\
\hline RB do Tinguá $\left(22^{\circ} 35^{\prime} 21^{\prime \prime} \mathrm{S} 43^{\circ} 29^{\prime} 04^{\prime \prime} \mathrm{W}\right)$ & 0.16 & 1,375 & Yes (prior to study) \\
RB de Araras $\left(22^{\circ} 26^{\prime} 58^{\prime \prime} \mathrm{S} 43^{\circ} 17^{\prime} 30^{\prime \prime} \mathrm{W}\right)$ & 19 & 1,650 & Yes (new location) \\
PN da Serra dos Órgãos & 44 & 2,010 & Yes (prior to study) \\
$\quad\left(22^{\circ} 28^{\prime} 16^{\prime \prime} \mathrm{S} 43^{\circ} 03^{\prime} 22^{\prime \prime} \mathrm{W}\right)$ & & 1,809 & No \\
Fazenda Itatiba $\left(22^{\circ} 21^{\prime} 27^{\prime \prime} \mathrm{S} 42^{\circ} 44^{\prime} 32^{\prime \prime} \mathrm{W}\right)$ & 53 & 1,830 & Yes (new location) \\
Nova Caledônia $\left(22^{\circ} 21^{\prime} 25^{\prime \prime} \mathrm{S} 43^{\circ} 34^{\prime} 06^{\prime \prime} \mathrm{W}\right)$ & 30 & & Not surveyed \\
Fazenda Amaral $\left(22^{\circ} 26^{\prime} 21^{\prime \prime} \mathrm{S} 42^{\circ} 30^{\prime} 44^{\prime \prime} \mathrm{W}\right)$ & 16 & 1,490 & No \\
Fazenda Boa Esperança & 13 & & No \\
$\quad\left(22^{\circ} 19^{\prime} 13^{\prime \prime} \mathrm{S} 42^{\circ} 15^{\prime} 38^{\prime \prime} \mathrm{W}\right)$ & & \\
PE do Desengano $\left(21^{\circ} 53^{\prime} 45^{\prime \prime} \mathrm{S} 41^{\circ} 54^{\prime} 33^{\prime \prime} \mathrm{W}\right)$ & 11 & & \\
Other fragments & 15 & & \\
Total & 201 & &
\end{tabular}

${ }^{*}$ RB, Reserva Biológica; PE, Parque Estadual; PN, Parque Nacional 
a 5-10 $\mathrm{m}$ canopy, similar to the habitat in which the species was previously recorded (Scott \& Brooke, 1993).

Parque Nacional da Serra dos Órgãos The team confirmed the presence of $T$. condita at the well-known site in Parque Nacional da Serra dos Órgãos. On 2 December 2003, at 2,010 m, they observed at least one, and probably two, pairs after playback. Again, they were in cloud forest rich in bromeliads.

Above Fazenda Itatiba This site was surveyed over 5-8 December 2003. The base camp, reached by helicopter, was at $1,800 \mathrm{~m}$ at the forest edge in grassland but with forest access up to c. 2,000 $\mathrm{m}$. The exit from the site by foot allowed considerable survey time in forests above $1,400 \mathrm{~m}$. No $T$. condita were heard, seen, or captured. T. atra were common.

Nova Caledônia On 29 October 2004 AF surveyed this area and located a single $T$. condita at $1,890 \mathrm{~m}$. After return visits over the next 18 months it was concluded there were at least three resident pairs. In a short visit on 21 July 2005 a team found two pairs that responded to playbacks at $1,844 \mathrm{~m}$. They were in forest with extensive bromeliads.

Fazenda do Amaral Efforts to reach the target site near Fazenda do Amaral were unsuccessful. A helicopter was unable to drop the team near the site and they only reached an elevation of $880 \mathrm{~m}$ by foot. Visual, auditory, and mist net surveys, over 10-12 January 2004, detected no individuals of T. condita. The team did hear T. atra during a brief hike that went above $1,000 \mathrm{~m}$.

Fazenda Boa Esperança Surveys were over 18-20 January 2004 at $1,490 \mathrm{~m}$ in high elevation grassland near the forest. The team set nets in the forest and surveyed by walking through the forest and on the ridges around the camp but there was no sign of $T$. condita. The team often heard T. atra in the forest below the camp. The landscape was similar to that of the Reserva Biológica de Araras.

Parque Estadual do Desengano Surveys began on 16 December 2003. The team left after c. 40 hours (mist nets set for only 4 hours) because of inclement weather. The exit from the site was by foot, allowing a survey down to $800 \mathrm{~m}$. The team heard T. atra often over 1,000-1,300 $\mathrm{m}$ but there was no evidence of $T$. condita. A return visit to the site for 1 day in February 2004, in good weather conditions, found no evidence of $T$. condita over $800-1,400 \mathrm{~m}$. T. atra was heard often below $1,300 \mathrm{~m}$.

\section{Discussion}

T. condita is poorly known, range-restricted, and lives within one of the most threatened biodiversity hotspots in the world. Ensuring its protection requires that we know where it lives. Our simple method, using basic geographic information system techniques and remotely sensed data, successfully predicted two new locations for the species. This doubled the known localities for the species and extended its confirmed range by $50 \mathrm{~km}$ east from previous sites. The model predicted several other locations but our surveys did not confirm the species there. There are two possible causes for these discrepancies. Either we do not know enough about the species to model its habitat adequately, or we simply did not find it when it was actually present.

If $T$. condita is truly absent from some predicted areas, then the specific reason remains unknown. One possibility is that the easternmost sites, Desengano and Fazenda Boa Esperança, are too dry. A precipitation map of the region suggests these areas receive $10-25 \%$ less rainfall than the other sites (Hijmans et al., 2005). Our impression was that these sites had substantially fewer bromeliads in the trees than other sites, although we made no systematic survey. Another possibility is that some habitat areas are too small to maintain viable populations. We have no data on area requirements for $T$. condita, nor how far it might travel between habitat patches. Given that the Tinguá site is $<_{1} \mathrm{~km}^{2}$ and yet contains the species, limited area does not seem to be a sufficient explanation. It is also possible that the species does not occur in the Fazenda Boa Esperança and Desengano sites because they are far from the remaining sites. This makes its absence from the Itatiba site puzzling, because the species occurs both to the east and west of this site.

We found T. atra at every site visited. It has been suggested that $T$. condita occurs at distinctly higher elevations than does its vocal congener, T. atra. This is true at the Araras site (this study) and the Serra dos Órgãos site (this study), and at Tinguá (MdeLB, pers. obs.). It is not, however, the case at the Nova Caledônia site where both species occur at broadly the same elevations. The reason for this is unknown. Further surveys to confirm the distribution of, and characterize the habitat of T. condita could help answer remaining questions, particularly at the Fazenda do Amaral site where we were unable to reach the predicted site.

Finally, we consider the conservation status of this species. About $200 \mathrm{~km}^{2}$ of forest habitat exists above $1,400 \mathrm{~m}$ under the most optimistic estimate of the species' range (Table 1). Discounting the two eastern sites reduces this by $24 \mathrm{~km}^{2}$. Moreover, at the largest predicted block of forest, Itatiba, we did not detect $T$. condita even above $1,800 \mathrm{~m}$ although its congener was common. The small, fragmented habitat confirms this species' categorization as Vulnerable under the IUCN D2 criterion (IUCN, 2001, 2007). Should there be any evidence that this habitat is being lost, the ranking should change to Endangered.

State and national parks formally protect much of this habitat but the actual status is less certain. Steep topography protects most of the sites, especially from the south, but humans do seem to be encroaching in some areas. At Nova Caledônia we heard chainsaws cutting a plantation of eucalyptus trees at the same time that we saw $T$. condita 
fly overhead. While those saws were not cutting native forest, the fact that they are so close is reason enough for concern.

\section{Acknowledgements}

We thank the National Geographic Society for financial support. The Coordenadoria Militar do Gabinete Civil made possible our preliminary flight. We also thank Universidade do Estado do Rio de Janeiro for the facilities to conduct field work, Conselho Nacional do Desenvolvimento Científico e Tecnológico (CNPq), Instituto Estadual de Florestas, IBAMA, and the land owners of private areas for permits to access the study sites, and CEMAVE/IBAMA for the permits and metal rings for birds. We particularly thank Gilmar from Fazenda Itatiba, Betinho from Parque Estadual do Desengano and Sr Eneas (from around Biovert, Pirineus) for their great help in the field. MASA received a $\mathrm{CNPq}$ (process no. 302718/03-6) grant while writing this paper.

\section{References}

Alves, M.A.S., Pacheco, J.F., Gonzaga, L.P., Cavalcanti, R.B., Raposo, M., Yamashita, C. et al. (2000) Aves. In A Fauna ameaçada de extinção do Estado do Rio de Janeiro (eds H.G. Bergallo, C.F.D. Rocha, M.A.S. Alves \& M. Van Sluys), pp. 113-124. Editora da Universidade do Estado do Rio de Janeiro, Rio de Janeiro, Brazil.

Collar, N.J., Gonzaga, L.P., Krabbe, N., Madroño Nieto, A. Naranjo, L.G., Parker III, T.A. \& Wege, D.C. (1992) Threatened Birds of the Americas: The ICBP/IUCN Red Data Book. International Council for Bird Preservation, Cambridge, UK.

HarRis, G.M., Jenkins, C.N. \& Pim M, S.L. (2005) Refining biodiversity conservation priorities. Conservation Biology, 19, 1957-1968.

Harris, G.M. \& Pimm, S.L. (2004) Bird species' tolerance of secondary forest habitats and its effects on extinction. Conservation Biology, 19, 1607-1616.

Hijmans, R.J., Cameron, S.E., Parra, J.L., Jones, P.G. \& Jarvis, A. (2005) Very high resolution interpolated climate surfaces for global land areas. International Journal of Climatology, 25, 1965-1978.

IBAMA (2007) Sistema Compartilhado de Informações Ambientais. $\mathrm{Http} / / /$ siscom.ibama.gov.br [accessed 4 June 2007].

IUCN (2001) 2001 Categories and Criteria (version 3.1). IUCN, Gland, Switzerland [http://www.redlist.org/info/categories_ criteria2001.html, accessed 4 June 2008].

IUCN (2007) 2007 IUCN Red List of Threatened Species. IUCN, Gland, Switzerland. Http://www.redlist.org [accessed 4 June 2008].

Jenkins, C.N. (2003) Importância dos remanescentes de Mata Atlântica e dos corredores ecológicos para a preservação e recuperação da avifauna do Estado do Rio de Janeiro. In Índice de Qualidade dos Municípios - Verde II. Fundação CIDE, Rio de Janeiro, Brazil.
Jenkins, C.N. \& Pimm, S.L. (2006) Definindo prioridades de conservação em um Hotspot de Biodiversidade Global. In Biologia da Conservação (eds C.F.D. Rocha, H.G. Bergallo, M. Van Sluys \& M.A.S. Alves), pp. 41-52. RiMa, São Carlos, Brazil.

Manne, L.L., Brooks, T.M. \& Pimm, S.L. (1999) Relative risk of extinction of passerine birds on continents and islands. Nature, $399,258-261$.

Myers, N. (1988) Threatened biotas: "Hot Spots" in tropical forests. The Environmentalist, 8, 187-208.

Myers, N. (1990) The biodiversity challenge: expanded hot-spots analysis. The Environmentalist, 10, 243-256.

Myers, N., Mittermeier, R.A., Mittermeier, C.G., Fonseca, G.A.B. \& Kent, J. (2000) Biodiversity hotspots for conservation priorities. Nature, 403, 853-858.

Pimm, S.L. \& Jenkins, C.N. (2005) Sustaining the variety of life. Scientific American, 293(3), 66-73.

Pimm, S.L., Raven, P., Peterson, A., Sekercioglu, C.H. \& EHRLich, P.R. (2006) Human impacts on the rates of recent, present, and future bird extinctions. Proceedings of the National Academy of Sciences, 103, 10941-10946.

Pimm, S.L., Russell, G.J., Gittleman, J.L. \& Brooks, T.M. (1995) The future of biodiversity. Science, 269, 347-350.

Rabus, B., Eineder, M., Roth, A. \& Bamler, R. (2003) The shuttle radar topography mission-a new class of digital elevation models acquired by spaceborne radar. ISPRS Journal of Photogrammetry \& Remote Sensing, 57, 241-262.

Rocha, C.F.D., Bergallo, H.G., Alves, M.A.S. \& van Sluys, M. (2003) A biodiversidade nos grandes remanescentes florestais do Estado do Rio de Janeiro e nas Restingas da Mata Atlântica. RiMa, São Carlos, Brazil.

Scott, D.A. \& Brooke, M. DE L. (1993) Rediscovery of the greywinged cotinga Tijuca condita in south-eastern Brazil. Bird Conservation International, 3, 1-12.

Snow, D. (1980) A new species of cotinga from southeastern Brazil. Bulletin of the British Ornithological Club, 100, 213-215.

SnOw, D. (1982) The Cotingas: Bellbirds, Umbrella Birds, and Other Species. Cornell University Press, Ithaca, New York.

\section{Biographical sketches}

Maria Alice Alves has research interests in bird ecology, including behavioural and population ecology and conservation, focusing on endemics and threatened species, particularly in the Atlantic Forest. STUART PIMM is interested in species extinctions and what can be done to prevent them. Alline STORNi has monitored fauna in the Amazon since 2005, measuring the impacts of ecotourism at Mamirauá Development Sustainable Reserve. Marcos Raposo specializes in bird evolution and systematics in the Neotropics. MICHAEL BROOKE is concerned with island conservation, setting global priorities for vertebrate eradications from islands and studying the raso lark in Cape Verde. Grant Harris models species and habitat relationships, with particular interests in conservation and extinction. Andy Foster is owner of Serra dos Tucanos Lodge in south-east Brazil, guiding birding tours and studying the avifauna of the Atlantic Forest. Clinton Jenkins has research interests in the prevention of biodiversity loss, designing biological corridors, and the use of remote sensing for threatened species management. 